\title{
Electronmicroscopic investigation of the effects of biocides on Pseudomonas aeruginosa PAO bacteriophage F116
}

\author{
J.-Y. MAILLARD*, A. C. HANN\$, T. S. BEGGS§, M. J. DAY†, R. A. HUDSON\| \\ and A. D. RUSSELL* \\ *Welsh School of Pharmacy, $\dagger$ Departments of Applied Biology and $\ddagger$ Physiology, University of Wales College of \\ Cardiff, Cardiff, §Unilever Research, Colworth House, Sharnbrook, Bedford MK $441 L Q$ and \| Lever Industrial \\ Development and Application Centre, PO Box 10, 3600 AA Maarssen. The Netherlands
}

\begin{abstract}
Summary. Electronmicroscopy was used to observe morphological changes of the Pseudomonas aeruginosa PA0 bacteriophage F116 when treated with various biocides commonly used as antibacterial and antifungal agents. Because of its large size $(145 \mathrm{~nm})$ and its organised structure (an isometric head and a tail), it was possible to classify structural damage into eight categories. The morphological changes induced depended on the type of biocide used and its concentration. Glutaraldehyde increased the number of phages with empty heads. Peracetic acid and phenol altered the appearance of the viral genome packaged inside the head, produced fractured heads, and damaged the tail. Peracetic acid also induced folding of the phage heads. The alcohols tested also altered the head structure. Cetylpyridinium chloride induced mainly fractured head damage. Chlorhexidine had little effect on the structure of F116.
\end{abstract}

\section{Introduction}

In the development of bacteriophage models for studying the effects of biocides on viruses, electronmicroscopy is a valuable tool. It has often been used to observe the diversity of bacteriophages found in natural environments ${ }^{1}$ or in sewage. ${ }^{2}$ It has also been employed to detect mammalian viruses ${ }^{3}$ and to analyse the processes of infection. ${ }^{4,5}$ However, it has been less used for studying viral morphological changes ${ }^{6}$ caused by the action of chemical agents, an exception being the studies of the effects of virucides upon hepatitis B virus. ${ }^{7-10}$

Coliphages are the most widely used viruses, in parallel with human viruses, to determine the efficacy of chemical disinfectants. ${ }^{11-14}$ However, other phages such as Bacteroides fragilis phage $\mathrm{B} 40-8^{15-16}$ and lactococcal phages $\mathrm{P} 001, \mathrm{P} 008$ and $\mathrm{P} 109^{13}$ have been studied also. The Pseudomonas aeruginosa PA0 phage F11 $16^{17}$ showed unexpected resistance to some biocides in suspension tests. ${ }^{18}$ Its large size $(145 \mathrm{~nm})$ and its well-defined structure (an isometric head and a tail) ${ }^{19}$ enabled electronmicroscopy to be used to investigate structural changes caused by biocides.

\section{Material and methods}

\section{F116 bacteriophage}

Bacteriophage F116 was propagated on $P$. aeruginosa $\mathrm{PAO} 1$ as described by Maillard et al. ${ }^{18}$ The lysates were stored at $4^{\circ} \mathrm{C}$.

\section{Biocides}

The biocides investigated were as follows, the choice of concentration being based on previous work: $:^{18}$ chlorhexidine diacetate $1 \% \mathrm{w} / \mathrm{v}(\mathrm{pH} 7)$, cetylpyridinium chloride $0.05 \% \mathrm{w} / \mathrm{v}(\mathrm{pH} 7)$, glutaraldehyde $1 \% \mathrm{v} / \mathrm{v}(\mathrm{pH}$ 8), ethanol $70 \% \mathrm{v} / \mathrm{v}$ and $100 \% \mathrm{v} / \mathrm{v}$, isopropanol $100 \% \mathrm{v} / \mathrm{v}$, phenol $0.5-2 \%$ $\mathrm{w} / \mathrm{v}(\mathrm{pH} 6)$ and peracetic acid 0.01-1\% v/v (pH 3.5). The negative control was phosphate-buffered saline (PBS, Oxoid; $\mathrm{pH}$ 7).

\section{Bacteriophage treatment}

One $\mathrm{ml}$ of lysate $\left(2 \times 10^{10} \mathrm{pfu} / \mathrm{ml}\right)$ was harvested by centrifugation for $15 \mathrm{~min}$ at $12000 \mathrm{rpm}$ in a microfuge (Clandon TH21, MLW). The pellet was resuspended for $10 \mathrm{~min}$ in $1 \mathrm{ml}$ of test biocide. A 20- $\mu \mathrm{l}$ sample was then mixed with $20 \mu \mathrm{l}$ of methylamine tungstate $1 \%$. After contact for $5 \mathrm{~min}$, a drop of the mixture was 
placed on a carbon-coated grid, which was blotted with filter paper to remove any excess liquid. The grid was examined in a Philips EM 400T electronmicroscope operating at $80 \mathrm{kV}$ accelerating voltage. F116 bacteriophages were observed at a magnification of 80000 . More detailed investigations of morphological changes were conducted at a magnification of 400000 .

\section{Results}

\section{Bacteriophage count and observation}

Each experiment was repeated three to five times, until a minimum number of 400 phages were counted for each exposure to a biocide concentration. A total of 15070 phage particles was examined. Statistical analysis $\left(\chi^{2}\right)$ of the phage counts was performed with the statistical software Minitab $^{\circledR}$ (Minitab Inc.). Initially, morphological changes of the phage particles were recorded and placed into four categories (table I): (a) intact phage (intact head attached to an intact tail) (fig. 1); (b) entire phage with head or tail damage, or both (figs. 2-5); (c) head with no tail present, with or without damage; (d) tail with no head present, with or without damage (figs. 6-7).

Subsequently, structural changes were investigated in more detail and divided into eight categories (table II): (a) intact phage (fig. 1); intact phage with (b) concentrated material (fig. 2) or (c) expanded material inside the head; (d) phage with a folded head structure (fig. 3); (e) phage with a fractured head structure (fig. 4); (f) intact phage with an empty head (fig. 5); (g) damaged tail (fig. 6); and (h) intact tail separated from the head (fig. 7). In this second experiment all of the bacteriophage heads which had separated from their tails appeared to be damaged. They were subsequently re-classified.

\section{Control}

In the first series of experiments, $72 \%$ of the phages in the control suspensions (table I; intact phage)

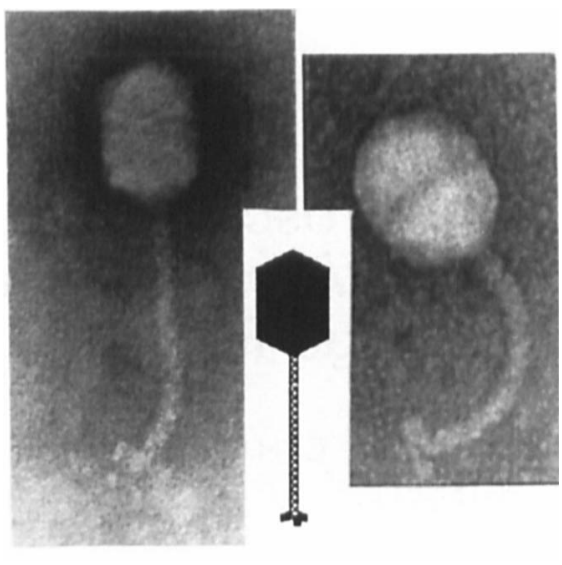

Fig. 1. F116 phage $(\times 400000)$.

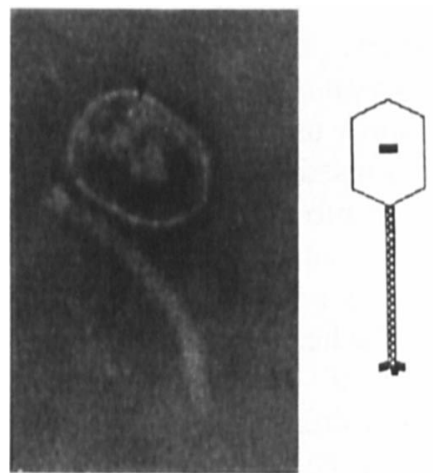

Fig. 2. F116 with concentrated material inside the head (arrow) $(\times 400000)$.

showed no structural alteration and in the second experiment, $86 \%$, (table II; intact phage). The detailed observations (table II) revealed that $6 \%$ of the particles consisted of tails isolated from the heads $(8.5 \%$ in table I). Of the phages observed, $3 \%$ were empty and another $3 \%$ showed condensed material inside the head. Only a small number of phages $(1 \%)$ had fractured heads.

Table I. Effect of chemical disinfectants on integrity of F116

\begin{tabular}{|c|c|c|c|c|c|c|}
\hline \multirow{2}{*}{\multicolumn{2}{|c|}{$\begin{array}{l}\text { Chemical disinfectant } \\
\text { and concentration }(\%)\end{array}$}} & \multicolumn{4}{|c|}{ Percentage of phages counted for each category } & \multirow{3}{*}{$\begin{array}{c}\begin{array}{c}\text { Total count } \\
\text { (tables I and II) }\end{array} \\
1268\end{array}$} \\
\hline & & \multirow{2}{*}{$\begin{array}{c}\begin{array}{c}\text { Intact } \\
\text { phage }\end{array} \\
76\end{array}$} & \multirow{2}{*}{$\begin{array}{c}\begin{array}{c}\text { Isolated } \\
\text { head }\end{array} \\
1\end{array}$} & \multirow{2}{*}{$\begin{array}{c}\begin{array}{c}\text { Isolated } \\
\text { tail }\end{array} \\
18\end{array}$} & \multirow{2}{*}{$\frac{\begin{array}{c}\text { Entire bacteriophage } \\
\text { with structural damage* }\end{array}}{5}$} & \\
\hline Chlorhexidine & 1 & & & & & \\
\hline Cetylpyridinium chloride & 0.05 & 0 & 0 & 29 & 71 & 1256 \\
\hline Glutaraldehyde & 1 & 19 & 2 & 10 & 69 & 1232 \\
\hline Ethanol & 70 & 2 & 21 & 37 & 40 & 1323 \\
\hline Ethanol & 100 & 52 & 6 & 25 & 17 & 1324 \\
\hline Isopropanol & 100 & 2 & 8 & 8 & 82 & 1184 \\
\hline \multirow[t]{3}{*}{ Phenol } & 0.5 & 61 & 21 & 3 & 15 & 484 \\
\hline & 1 & 48 & 21 & 11 & 20 & 1210 \\
\hline & 2 & 13 & 32 & 30 & 25 & 1311 \\
\hline \multirow[t]{3}{*}{ Peracetic acid } & 0.01 & 38 & 16 & 8 & 38 & 499 \\
\hline & $0 \cdot 1$ & 31 & 15 & 41 & 13 & 1353 \\
\hline & 1 & 0 & 59 & 0 & 41 & 1349 \\
\hline PBS (control) & & 72 & $6 \cdot 5$ & $8 \cdot 5$ & 13 & 1277 \\
\hline
\end{tabular}

*Head or tail damage, or both. 


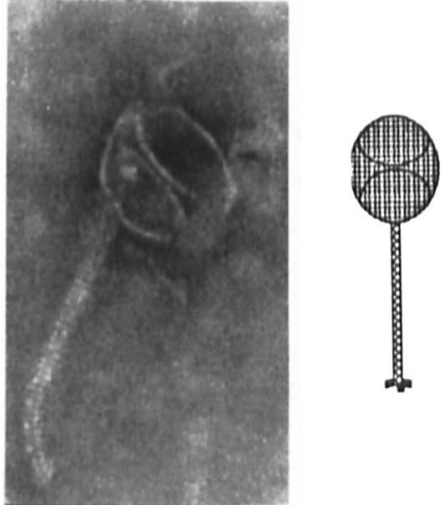

Fig. 3. F116 with a folded head structured (arrow) $(\times 400000)$

\section{Effect of biocides}

For each category of damage, the numbers of phage particles in the control differed significantly $(p<0.05)$ from the numbers of phages in the biocide-treated suspensions.

All biocides except peracetic acid ( $1 \% \mathrm{v} / \mathrm{v})$ induced a high percentage of separation of head and tail. The total number of independent heads did not always correlate with the number of isolated tails. Generally, the number of independent tails was higher than the number of isolated heads, except for peracetic acid $(1 \%$ and $0.01 \% \mathrm{v} / \mathrm{v})$, and phenol $(1 \%$ and $0.5 \%$ $\mathrm{w} / \mathrm{v})$. The number of independent tails and heads was similar for control phage suspensions (treated with PBS) and for phage suspensions treated with isopropanol $(100 \% \mathrm{v} / \mathrm{v})$ and phenol $(2 \% \mathrm{w} / \mathrm{v})$. The

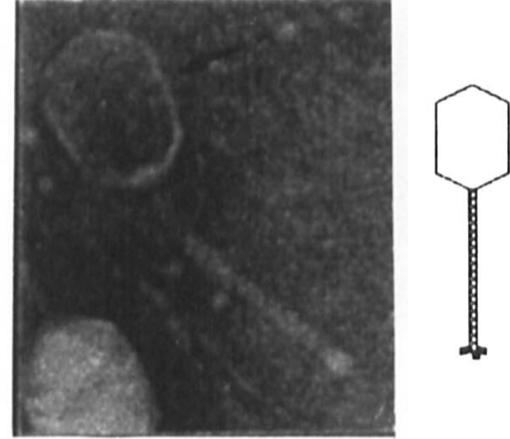

Fig. 5. F116 with an empty head (arrow) $(\times 400000)$.

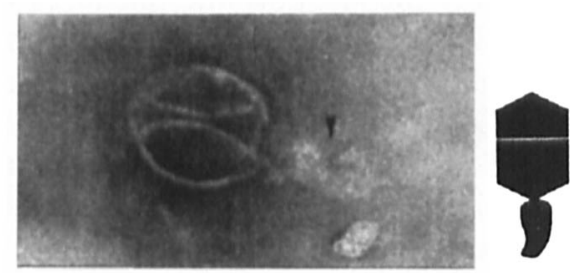

Fig. 6. F116 with a damaged tail (arrow) $(\times 400000)$.

percentage of separated tails counted in the two experiments (tables I and II; isolated tail) was similar.

Only phenol and peracetic acid produced bacteriophages with condensed material inside the
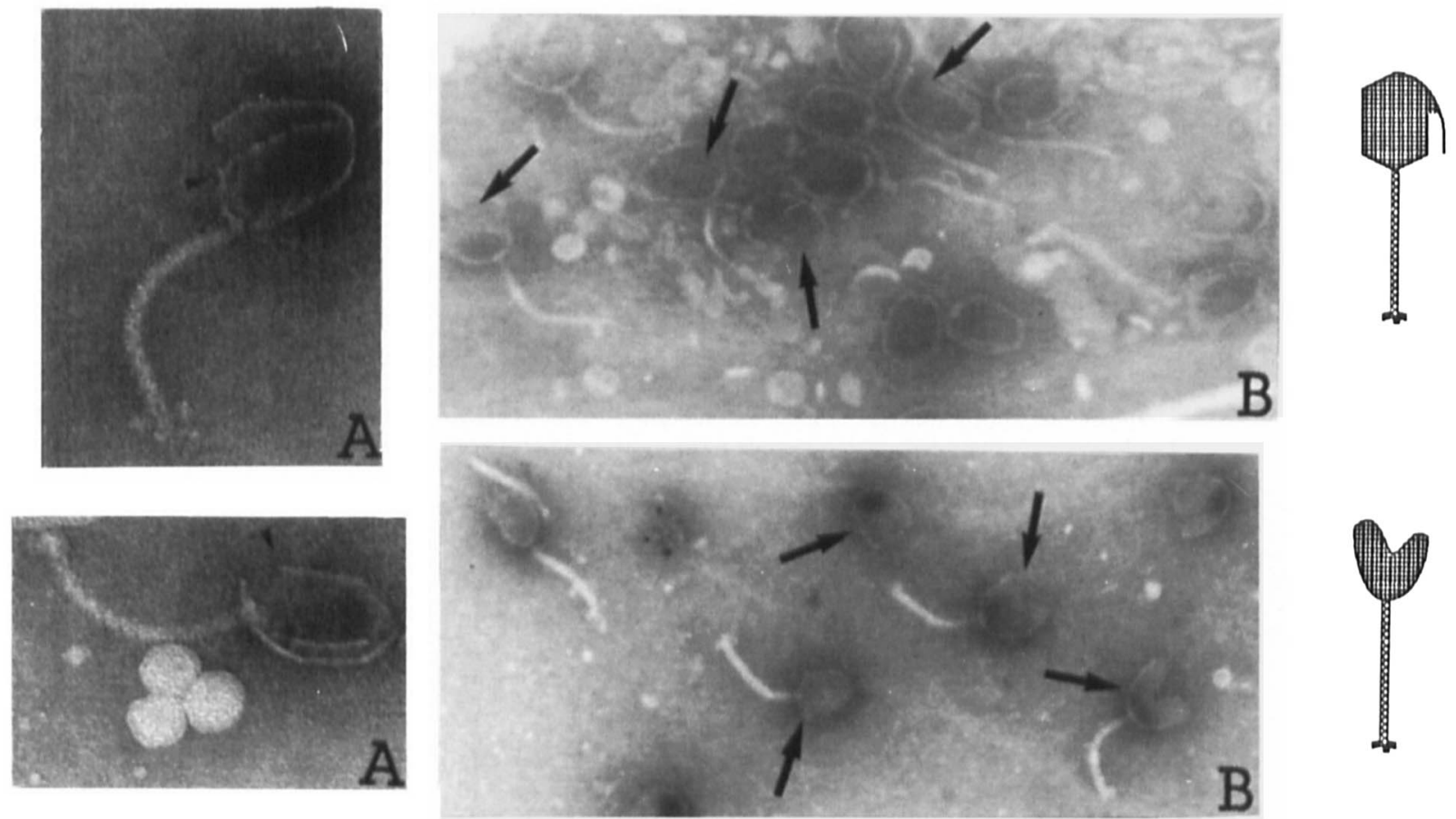

Fig. 4. F116 with a broken head structure (arrows): A, $\times 400000 ; \mathbf{B}, \times 80000$. 


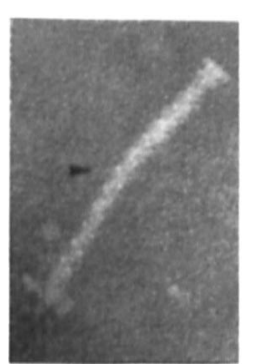

$$
1
$$

Fig. 7. Intact tail (arrow) separated from the head $(\times 400000)$.

head (table II). Higher concentrations of biocides correlated with a higher damage count $-12 \%$ for phenol $2 \% \mathrm{w} / \mathrm{v}$ and $11 \%$ for peracetic aid $1 \% \mathrm{v} / \mathrm{v}$.

Glutaraldehyde $1 \% \mathrm{v} / \mathrm{v}$ was the only biocide to induce a high number (52\%) of empty heads ("ghost phages")..$^{20}$ Only the alcohols and phenol altered the head to a folded structure (table II). The number of phages with this type of damage increased in frequency with a higher concentration of phenol. A small number of phages $(<10 \%$, but still higher than the control) was observed with this type of structural alteration when F116 was treated with either glutaraldehyde $1 \%$ $\mathrm{v} / \mathrm{v}$ or peracetic acid $0 \cdot 1 \%$ and $1 \% \mathrm{v} / \mathrm{v}$.

All the biocides tested induced a fractured head type of damage (table II). However, at $1 \% \mathrm{w} / \mathrm{v}$ both chlorhexidine and phenol produced only a small percentage of fractured structures $(4 \%$ and $2 \%$ respectively). This percentage was higher than the control $(1 \%)$. The highest percentages $(68.5 \%, 61 \%)$ were observed when F116 was treated with cetylpyridinium chloride $0.05 \% \mathrm{w} / \mathrm{v}$ and isopropanol $100 \% \mathrm{v} / \mathrm{v}$, respectively. Ethanol $70 \% \mathrm{v} / \mathrm{v}$ altered the head structure to a greater extent $(32 \%)$ than absolute ethanol $(15 \%)$.

Damaged tails were observed only when F116 was pre-treated with phenol or peracetic acid. At a lower phenol concentration, there was a higher number of damaged tails.

\section{Discussion}

The damage observed in the untreated phage lysate is likely to be the result of background abnormalities. This phenomenon has been described previously with coliphage $\lambda^{21}$. The difference in control phage counts between tables I and II is probably due to natural differences between lysates, although the titres were the same.

The severity of the damage caused by biocides, observed by electronmicroscopy, did not correlate with the loss of phage titre measured by the virus suspension test. ${ }^{12}$ Phenol $2 \% \mathrm{w} / \mathrm{v}$, peracetic acid $1 \% \mathrm{v} / \mathrm{v}$, cetylpyridinium chloride $0.05 \% \mathrm{w} / \mathrm{v}$ and glutaraldehyde $1 \% \mathrm{v} / \mathrm{v}$ altered the phage structure in a well defined way. The first three biocides were found to reduce the F116 titre by at least $4 \log _{10}{ }^{18}$

Higher biocide concentrations increased the proportion of damaged phages, but did not alter the types of structural damage. Thus phenol and peracetic acid produced a similar pattern of damage, as did the alcohols tested.

Glutaraldehyde $1 \% \mathrm{v} / \mathrm{v}$ produced a $3 \log _{10}$ reduction in titre within 20 min. ${ }^{18}$ At a concentration of $\leqslant 2 \%$, it has been found to be effective against poliovirus, ${ }^{22,23}$ rotavirus, ${ }^{24}$ hepatitis B virus, ${ }^{25,}{ }^{26}$ hepatitis $\mathrm{A}$ virus ${ }^{27}$ and herpes virus. ${ }^{28}$ Chambon et al. ${ }^{29}$ showed that one of the glutaraldehyde targets was the capsid of poliovirus type I and echovirus type 25 . In the present study, most of the phage particles treated with glutaraldehyde $1 \% \mathrm{v} / \mathrm{v}$ had a "ghostly" appearance. It is possible that the biocide altered the protein structure, triggering the mechanism causing the phage genome to be ejected into the surrounding medium. If the nucleic acid is released, it remains to be determined whether glutaraldehyde inactivates the F116 phage genome. It has been shown that the RNA genome of poliovirus type 1 was resistant to glutaraldehyde up to a concentration of $1 \%{ }^{23}$

Both phenol and peracetic acid were highly effective against F116. ${ }^{18}$ Phenol is a potent agent against

Table II. F116 structural damaged caused by chemical disinfectants

\begin{tabular}{|c|c|c|c|c|c|c|c|c|c|}
\hline \multirow{2}{*}{$\begin{array}{c}\text { Chemical } \\
\text { disinfectant } \\
\text { and } \\
\text { concentration } \\
(\%)\end{array}$} & & \multicolumn{8}{|c|}{ Percentage of phages counted for each category } \\
\hline & & $\begin{array}{l}\text { Intact } \\
\text { phage }\end{array}$ & $\begin{array}{l}\text { Expanded material } \\
\text { inside head }\end{array}$ & $\begin{array}{l}\text { Condensed material } \\
\text { inside head }\end{array}$ & $\begin{array}{c}\text { Folded } \\
\text { head }\end{array}$ & $\begin{array}{c}\text { Fractured } \\
\text { head }\end{array}$ & $\begin{array}{l}\text { Empty } \\
\text { head }\end{array}$ & $\underset{\text { tail }}{\text { Damaged }}$ & $\begin{array}{l}\text { Intact tail separated } \\
\text { from head }\end{array}$ \\
\hline Chlorhexidine & 1 & 81 & 0 & 0 & 0 & 4 & 0 & 0 & 15 \\
\hline $\begin{array}{l}\text { Cetylpyridinium } \\
\text { chloride }\end{array}$ & 0.05 & 0 & 1 & 0 & 3 & 69 & 0 & 0 & 27 \\
\hline Glutaraldehyde & 1 & 20 & 0 & 1 & 5 & 13 & 52 & 0 & 9 \\
\hline Ethanol & 70 & 11 & 0 & 0 & 20 & 32 & 0 & 0 & 37 \\
\hline Ethanol & 100 & 41 & 0 & 1 & 18 & 15 & 0 & 1 & 24 \\
\hline Isopropanol & 100 & 3 & 0 & 0 & 23 & 61 & 0 & 0 & 13 \\
\hline \multirow[t]{2}{*}{ Phenol } & 1 & 47 & 2 & 5 & 17 & 2 & 2 & 13 & 12 \\
\hline & 2 & 11 & 1 & 12 & 35 & 11 & 0 & 4 & 26 \\
\hline \multirow[t]{2}{*}{ Peracetic acid } & $0 \cdot 1$ & 33 & 0 & 4 & 3 & 13 & 6 & 1 & 40 \\
\hline & 1 & 0 & 0 & 11 & 8 & 44 & 0 & 37 & 0 \\
\hline PBS (control) & & 86 & 1 & 3 & 0 & 1 & 3 & 0 & 6 \\
\hline
\end{tabular}


enveloped viruses, and modifies bacterial membrane permeability. ${ }^{30}$ Enteroviruses, such as poliovirus, were found to be more resistant to peracetic acid ${ }^{31}$ than rotaviruses. ${ }^{32}$ However, no morphological changes were described. Phenol and peracetic acid had similar effects on F116. Both induced a change in appearance of the viral genome packaged inside the head, possibly resulting from an alteration of the head permeability, and, therefore, of the osmotic pressure. This may produce the fractured heads observed in some instances. The two biocides were also highly active against the tail proteins, causing an aggregation of material (fig. 6).

Ethanol $70 \%$ and isopropanol $60-70 \%$ are usually considered to be powerful virucidal agents against enveloped viruses. However, non-enveloped viruses such as poliovirus are more resistant to these disinfectants. ${ }^{22}$ Enveloped viruses, such as herpes virus, ${ }^{28}$ are more resistant to high $(100 \%)$ than to lower $(60-70 \%)$ concentrations of alcohols. The alcohols tested probably targeted structural proteins involved in conferring the internal structure of the head. Ethanol $100 \% \mathrm{v} / \mathrm{v}$ and isopropanol $100 \% \mathrm{v} / \mathrm{v}$ produced a higher reduction of F116 titre than ethanol $70 \% \mathrm{v} / \mathrm{v}^{12}$ However, more damage was observed when F116 was treated with ethanol $70 \% \mathrm{v} / \mathrm{v}$ rather than absolute ethanol. This is a contradiction, unless the phage genome remains highly infective. Virucidal damage might not necessarily be correlated with an alteration of the phage structure.

Quaternary ammonium compounds are generally active against enveloped viruses. Cetylpyridinium chloride was highly active against F116. ${ }^{18}$ Damage was a severe fracturing of the head.

\section{References}

1. Demuth J, Neve H, Witzel K-P. Direct electron microscopy study on the morphological diversity of bacteriophage populations in Lake Plufsee. Appl Environ Microbiol 1993; 59: 3378-3384.

2. Ackermann H-W, Nguyen T-M. Sewage coliphages studied by electron microscopy. Appl Environ Microbiol 1983; 45: 1049-1059.

3. Whitby HJ, Rodgers FG. Detection of virus particles by electron microscopy with polyacrylamide hydrogel. J Clin Pathol $1980 ; 33: 484-487$.

4. Pemberton JM. F116: A DNA bacteriophage specific for the pili of Pseudomonas aeruginosa strain PAO. Virology 1973; 55: $558-560$.

5. Bamford DH, Lounatmaa K. Further electron microscopic studies on the infection process of the lipid-containing bacteriophage phi6. J Gen Virol 1982; 61: 149-152.

6. Rodgers FG, Hufton P, Kurzawska E, Molloy C, Morgan S. Morphological response of human rotavirus to ultra-violet radiation, heat and disinfectants. J Med Microbiol 1985; 20: $123-130$.

7. Howard CR, Dixon J, Young P, Van Eerd P, Schellekens H. Chemical inactivation of hepatitis $B$ virus: the effect of disinfectants on virus-associated DNA polymerase activity, morphology and infectivity. J Virol Methods 1983; 7: 135-148.

8. Thraenhart $\mathrm{O}$, Dermietzel $\mathrm{R}$, Kuwert $\mathrm{E}$, Scheiermann $\mathrm{N}$. Morphological alteration and disintegration of Dane particles after exposure with "Gigasept". A first methodological attempt for the evaluation of the virucidal
Chlorhexidine is a powerful antibacterial agent. ${ }^{30} \mathrm{It}$ has also been shown to be effective against the enveloped human immunodeficiency virus (HIV). ${ }^{33}$ However, chlorhexidine diacetate $1 \% \mathrm{w} / \mathrm{v}$ is ineffective against $\mathrm{F} 116$ bacteriophage. $^{18}$ In this study, little structural change was observed, reinforcing the idea that this agent is not effective against this bacteriophage. In a parallel study with an energy dispersive analyser of X-rays fitted into the electronmicroscope, it was noticed that chlorhexidine was poorly bound to the phage surface (unpublished data), which could explain the lack of activity of this disinfectant. In contrast, cetylpyridinium chloride binds to the phage surface (unpublished data).

All the biocides tested, except chlorhexidine, induced various types of structural damage, subsequently releasing the nucleic acid packaged in the head. It is yet to be determined whether the phage nucleic acid is then inactivated, or whether it remains infectious. F116 bacteriophage appears to be a suitable model for such purposes because of its large doublestranded DNA content, which could be easily extracted and purified at a high yield.

F116 phage differs morphologically from human viruses in that it possesses a head and a tail. F116 does not have an envelope, although it does contain some lipid. Nevertheless, exposure of F116 to biocides produces quite marked morphological changes which could ultimately be linked to the mechanisms of virucidal action of these agents against human and animal viruses.

efficacy of a chemical disinfectant against hepatitisvirus B. Zentralbl Bakteriol Hyg, I Abt Orig B 1977; 164: 1-21.

9. Thraenhart O, Kuwert EK, Dermietzel R, Scheiermann N, Wendt $F$. Influence of different disinfection conditions on the structure of the Hepatitis B virus (Dane particle) as evaluated in the morphological alteration and disintegration test (MADT). Zentralbl Bakteriol Hyg, I Abt Orig A 1978; 242: 299-314.

10. Thraenhart $\mathrm{O}$, Kuwert EK. Hepatitis-Viruzidie chemischer Desinfektionsmittel. Münch Med Wschr 1980; 122: 357-359.

11. Thurman RB, Margolin AB, Rockow JP, Janauer GE, Costello MJ, Gerba CP. Characterization of the interaction between viruses and a solid polymeric contact disinfectant. $J$ Environ Sci Health 1988; 23 : 405-423.

12. Kaneko M. Effect of suspended solids on inactivation of poliovirus and T2 phage by ozone. Water Sci Tech 1989; 21: $215-219$

13. Rheinbaben FV, Bansemir K-P, Heinzel M. Virucidal effectiveness of some commercial disinfectants for chemothermal disinfection procedures tested against temperature resistant viruses and bacteriophages-Evaluation of a test model. Zentralbl Hyg 1992; 192: 419-431.

14. Davies JG, Babb JR, Bradley CR, Ayliffe GA. Preliminary study of test methods to assess the virucidal activity of skin disinfectants using poliovirus and bacteriophages. $J$ Hosp Infect 1993; 25: 125-131.

15. Tartera C, Bosch A, Jofre J. The inactivation of bacteriophages infecting Bacteroides fragilis by chloride treatment and UV-irradiation. FEMS Microbiol Lett 1988; 56: 313-316.

16. Pintó RM, Abad FX, Roca RM, Riera JM, Bosch A. The use of 
bacteriophages of Bacteroides fragilis as indicators of the efficiency of virucidal products. FEMS Microbiol Lett $1991 ; 82: 61-66$

17. Holloway BW, Egan JB, Monk M. Lysogeny in Pseudomonas aeruginosa. Aust J Exp Biol Med Sci 1960; 38: 321-329.

18. Maillard J-Y, Beggs TS, Day MJ, Hudson RA, Russell AD. Effect of biocides on Pseudomonas aeruginosa phage F116. Lett Appl Microbiol 1993; 17: 167-170.

19. Miller RV, Pemberton JM, Richards KE. F116, D3 and G101: Temperate bacteriophages of Pseudomonas aeruginosa. Virology 1974; 59: 566-569.

20. Douglas J (ed). Bacteriophages. London, Chapman and Hall Ltd. 1975.

21. Murialdo $\mathbf{H}$, Siminovitch $\mathrm{L}$. The morphogenesis of phage lambda. V. Form-determining function of the genes required for assembly of the head. Virology 1972; 48: $824-835$.

22. Tyler R, Ayliffe GAJ, Bradley C. Virucidal activity of disinfectants: studies with the poliovirus. $J$ Hosp Infect 1990; 15: 339-345.

23. Bailly J-L, Chambon M, Peigue-Lafeuille H, Laveran H, De Champs C, Beytout D. Activity of glutaraldehyde at low concentrations $(<2 \%)$ against poliovirus and its relevance to gastrointestinal endoscope disinfection procedures. Appl Environ Microbiol 1991; 57: 1156-1160.

24. Lloyd-Evans N, Springthorpe VS, Sattar SA. Chemical disinfection of human rotavirus-contaminated inanimate surfaces. J Hyg 1986; 97: 163-173.
25. Bond WW, Favero MS, Petersen NJ, Ebert JW. Inactivation of hepatitis B virus by intermediate-to-high level disinfectant chemicals. J Clin Microbiol 1983; 18: 535-538.

26. Kobayashi H, Tsuzuki M, Koshimizu K et al. Susceptibility of hepatitis B virus to disinfectants or heat. J Clin Microbiol $1984 ; 20: 214-216$.

27. Passagot J, Crance JM, Biziagos E, Laveran H, Agbalika F, Deloince R. Effect of glutaraldehyde on the antigenicity and infectivity of hepatitis A virus. J Virol Methods 1987; 16: $21-28$.

28. Tyler R, Ayliffe GA. A surface test for virucidal activity of disinfectants: preliminary study with herpes virus. $J$ Hosp Infect $1987 ; 9: 22-29$.

29. Chambon M, Bailly J-L, Peigue-Lafeuille H. Activity of glutaraldehyde at low concentrations against capsid proteins of poliovirus type 1 and echovirus type 25 . Appl Environ Microbiol 1992; 58: 3517-3521.

30. Russell AD, Chopra I. Understanding antibacterial action and resistance. New York, Ellis Horwood. 1990.

31. Baldry MGC, French MS, Slater D. The activity of peracetic acid on sewage indicator bacteria and viruses. Water Sci Tech 1991 ; 24 : 353-357.

32. Harakeh MS. Inactivation of enteroviruses, rotaviruses and bacteriophages by peracetic acid in a municipal sewage effluent. FEMS Microbiol Lett 1984; 23 : 27-30.

33. Montefiori DC, Robinson WE, Modliszewski A, Mitchell WM. Effective inactivation of human immunodeficiency virus with chlorhexidine antiseptics containing detergents and alcohol. J Hosp Infect 1990; 15: 279-282. 